\title{
The Analysis of Child Bullying Behaviour of Game Mobile Learning Users, in The Early Childhood Education Management Perspective
}

\author{
https://doi.org/10.3991/ijim.v15i09.21583 \\ Eny Nur Aisyah $\left.{ }^{(}\right)$, Harun, Arif Rohman, Hardika Hardika \\ Universitas Negeri Malang, Malang, Indonesia \\ Universitas Negeri Yogyakarta, Yogyakarta, Indonesia \\ eny.nur.fipeum.ac.id / enynur.2020estudent.uny.ac.id
}

\begin{abstract}
This study aims to analyze the behavior of verbal bullying, social bullying, and physical bullying in early childhood using game mobile learning. The research approach used is qualitative phenomenology. The informants of this study were 24 parents, 3 teachers, and 30 children aged 4-6 years in Early Childhood Education Institutions in Indonesia. Data were collected through indepth interviews, observation, and documentation study. Based on the results of data analysis, it is known the behavior of verbal bullying, social bullying, and physical bullying there are differences in the intensity and frequency of bullying behavior of children aged 4-6 years while playing game mobile learning at home and in social settings. Unconsciously, bullying behavior is formed and developed from an early age through game mobile learning used by children. Children do not understand the meaning of bullying behavior which is shown through attitudes, words, and behavior when playing game mobile learning. So, the closest adults to the child are needed (1) to manage learning activities using game mobile learning, (2) provide intensive assistance for children when playing game mobile learning, (3) provide good advice and admonitions when bullying behavior is presented by the child, (4) agree on clear rules, and (5) firmly with children when playing game mobile learning.
\end{abstract}

Keywords - Bullying behavior, game mobile learningchildren

\section{Introduction}

The variety and types of game mobile learning are growing rapidly aimed to provide convenience in facilitating children's learning in a fun way [1], it has another side that must be revealed more deeply. The flexibility, efficiency, and various conveniences found in the game mobile learning application are considered to be able to answer all developmental problems and achieve children's learning goals and demands, with or without the assistance of adults around them [2], [3]. Types of games, play games, action games, and other types of learning games have a good impact on improving student learning [4]. It is regardless of the impact of how children's character formation during and after playing game mobile learning. In the learning process, 
learning games have different learning outcomes as well as traditional games that previously existed in children's play activities [5], [6]. New behaviors and habits emerge according to the needs and goals of education and nurture to be achieved by the closest people around the child and no longer based on the child's interests and wishes or vice versa. Several new behaviors that have emerged have become habits that require more intensive prevention and assistance due to the presence of a game of mobile learning.

Bullying is a phenomenon of behavior deviations committed by individuals or groups of people who can give a negative impact on bullied victims [7]. This bullying behavior can occur and be done by people intentionally or unintentionally [8]. Data on bullying behavior from year to year continues to increase, both in terms of the number of perpetrators and victims, the quality of bullying, and its impact on the individual, social, mental, and moral [9]. Victims of bullying can happen to anyone and from any social class, be it from upper or lower social class [10]. It can happen because bullying behavior is often not based on rationality and a healthy mindset rather than based on the absolute interests of the perpetrator [11].

Related to this phenomenon bullying has become the center of attention and studies from various groups, both from practitioners, academics, and observers. Bullying can occur physically, verbally, socially, sexually, and cyber-bullying [12]. Bullying is a form of violence that has legal sanctions if someone is proven to have committed [13]. Strictly speaking in the world and Indonesia, especially children who are victims of bullying have legal protection. Both bullying verbally, physically, and psychologically through Law No. 35 of 2014 concerning Amendments to Law No. 23 of 2002, concerning the Child Protection Law has regulated the existence of a guarantee of legal protection, both from the victim and the bullying [14].

Some cases of bullying in early childhood occur due to a lack of supervision from teachers, parents, and the surrounding environment [15]. Parents and families are also too lax in applying the rules, and the authorities do not have a firm attitude and viewpoint against bullying. Kindergarten teachers also have limited knowledge of bullying [16]. Several studies have shown that boys are more likely to engage in bullying than girls [10]. Also, girls are more likely than boys to become victims of bullying [17]. An Australian study of 38,000 children found that $22.1 \%$ of girls admitted to being bullied by boys, and as much as $3.4 \%$ of boys admitted to being bullied by girls (Rigby, 2003). It shows that boys are more bullying than girls. Usually, boys do bullying behavior physically, while girls usually bullying behavior in the form of verbal, mental, and social [18]. Bullying is a habit pattern that is considered normal, it is increasingly difficult to distinguish both the perpetrator and the victim [19]. The emergence of deviant behavior due to bullying is finally seen as strange by the community and becomes an urgent need that must be resolved immediately through synergies in the management of education in schools and care at home, with macro-community involvement around children from an early age.

The rapid development of technology and the progress of the times resulted in parents and teachers of early childhood experiencing indirect changes in the patterns of care and management of education in schools [20]. Good education management is the key to successful learning outcomes [21]. Especially during a pandemic like to- 
day, teachers and parents are still required to be able to provide education that is relevant to the progress of the times and the development of children [22]. Limitations of parents regarding mastery of knowledge and finance should not be used as an excuse in meeting children's learning needs, even though parents cannot full fill all of their children's learning needs [23]. Electronic equipment such as gadgets that have now become one of the children's learning needs at home must also be fulfilled by parents as a form of responsibility for children's learning continuity [24]. It eventually becomes a problem for some parents and teachers in carrying out educational activities because of the limited availability of learning facilities. On the other hand, meeting the needs for learning equipment in the form of cell phones as a medium for learning at home must be fulfilled along with the Covid-19 pandemic period requires children to study at home. [25].

The presence of electronic game tools for learning car games in social interaction and learning in children's environments makes the learning process change incredibly fast, creative, and full of innovations [1], [26]. Technology-based, a variety of online learning education services are available on sites that are easily accessible to children and adults around [27]. The Intelligence and expertise of adults around children to be able to choose the right learning application that can be accessed through online media is needed. This is necessary to fit the goals and development of children in learning [1]. Game mobile learning is a form of educational service that is fun, motivates, and enhances children's creativity from an early age [2].

Game mobile learning in various countries has various impacts on children's learning processes [28]. In Australia, game mobile learning helps children to form attitudes and behaviors. In Malaysia, children are also more motivated and enthusiastic in improving their academic abilities [29]. However, game mobile learning also has a very high negative impact on children [30]. This can happen because a lot of game mobile learning content triggers negative behavior, such as content about violence, competitions that require children to take sides, the cultural culture that is not appropriate for the child's development stage [31]. Children tend to get angry when they are wrong or lose, tease and curse people around them, sometimes slamming the mobile learning tools used. This condition is unavoidable and must be accepted, because nearly $89 \%$ of pre-school children in the world practice learning methods. the same through game mobile learning [32].

Regarding the various advantages, disadvantages, advantages, and disadvantages of using game mobile learning in early childhood, data is needed regarding the negative effects of using game mobile learning, especially bullying behavior that has the potential to harm other parties. How bullying behavior can be avoided through an appropriate and targeted use management for children. So that basic data is needed as a form of efforts to tackle bullying behavior in children from an early age, so this study seeks to analyze verbal bullying, social bullying, and physical bullying in children aged 4-6 years, due to the intensity of using game mobile learning, both at home. and the child's social environment. 


\section{Research Methodology: Data and Sample Size}

This study aims to reveal in-depth the bullying behavior of early childhood users of the Game mobile learning. Bullying behavior in these children is analyzed based on the characteristics and intensity of three types of bullying behavior, namely: verbal bullying, social bullying, and physical bullying. The research approach used is qualitatively based on phenomenological studies. The subjects of this study were 24 parents and 30 children aged 4-6 years who registered as students in Early Childhood Education Institutions in Indonesia. The Early Childhood Education Institutions was the target of this study was selected purposively which could support the achievement of the research objectives. The parameters used as the basis for choosing an early childhood education institution as the target of this study are (1) readiness of the institution to accept researchers, (2) ownership of game mobile learning devices by students, (3) readiness of parents to provide information about game mobile learning, and (4) the feasibility and appropriateness of the location where the child and parents live to be physically attended by researchers related to the COVID-19 situation.

The research data were collected using in-depth interviews, observation, and documentation study. In-depth interviews and observations were conduct at the child's place of residence and children's play area. Documentation studies conducted on the existence of stored information, both in the form of writing and images related to prominent events experienced by children when playing game mobile learning. The document can be stored on electronic equipment, printing devices, or in other places that can be considered as data. Data analysis was carried out interactively as long as data collection took place to completion, which included the steps (1) data collecting, (2) data reduction, (3) data display, (4) data verification, and (5) conclusion. The process of implementing this research was carried out by a team, which consisted of three people, assisted by data collectors from student elements of the Early Childhood Education Teacher Education Study Program, State University of Malang.

\section{$3 \quad$ Findings and Discussion}

The findings and discussion of this research are presented in graphical and narrative form from each focus of the finding namely is verbal bullying, physical bullying, and social bullying. The analysis in the form of a narrative about bullying behavior will be analyzed by the case for ages 4 years, 5 years, and 6 years.

\subsection{Verbal bullying}

Figure 1 explained there are seven types of verbal bullying found in this study, namely (1) swear (2) rebuke, (3) profanity, (4) calling inappropriate names, (5) mocking, (6) insulting, and (7) threatening. Of the seven findings, all of them were experienced and carried out by early childhood groups of 4-6 years. Children aged four years often do verbal bullying in the form of rebuke, mocking, swear, threatening, and insulting. Such bullying is relatively easy for 4-year-olds to say. The frequency of 
appearance of these words and the ease with which children aged four years old make bully swear rebuke, and profanity easier to slide from the words of young children. The ability of early childhood to record and imitate messages circulating in the environment is one of the factors causing the emergence of verbal bullying among 4-yearolds.

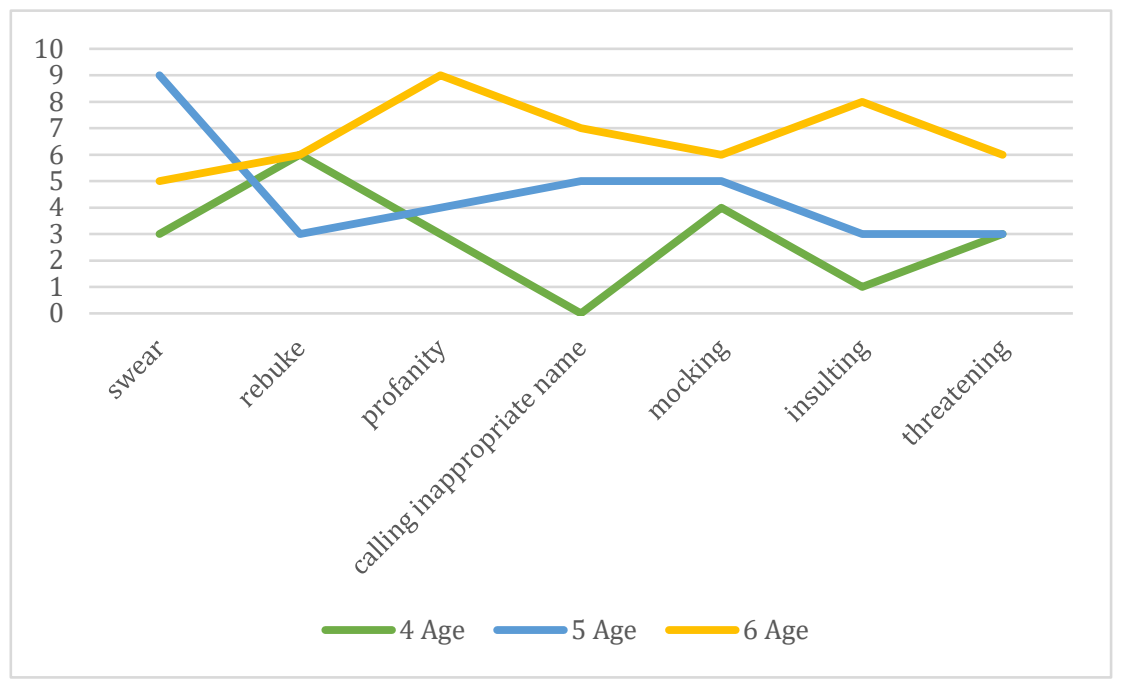

Fig. 1. The Data Graph of Types and Intensity of Verbal Bullying

Children aged five years have different verbal bullying behavior and abilities with those under and over. Age 5 years old dominantly tends to do verbal bullying in the form of swear, mocking, calling inappropriate names, and profanity. This data can be explained, that there has been an increase in the understanding and richness of vocabulary about terms heard in the environment. Children aged five years also can make self-name associations with other social phenomena. The transfer of a child's nickname with another nickname that has a worse connotation can also be said to be high cognitive and affective abilities for children of that age. In the perspective of cognitive psychology, the child's ability to do verbal bullying using unusual terms is part of the development of children's intelligence [8]. However, the role of educators is needed to supervise, control, direct, correct, and at the same time warn against verbal bullying in early childhood [7], [33]. Early childhood educators must have a wealth and educational style that is adaptive to the development of information technology so that the messages conveyed by educators can be well received by students. [34], [35]. The selection of appropriate words, the right place, polite intonation of the language, and physical and psychological closeness received by children will make learning messages from educators will be very effective in the process of changing students' attitudes [36], [37].

For children aged six years, verbal bullying behavior that often appears are profanity, insulting, and calling in an appropriate name. The types of bullying that appear to the perpetrators are almost the same as for children aged five years. A rather sharp 
difference from the data in graph 2 is the number of perpetrators, namely 8-10 children who bully. This number is relatively large because it reaches $33 \%$ more than the total number of subjects in this study. In a social psychology review, the ability to interact with others, be it at home, school, or in the community will always create social and psychological advantages and disadvantages. From the perspective of child development, changes in behavior and attitudes always cannot be separated from the influence of the child's social environment [38]. The social environment makes a big contribution to the formation of children's behavior, including the ability and courage to carry out deviant behavior in the environment where they live. Children will develop following the innate character and environmental influences even though each child will experience different development processes and results, both in terms of the quality of intelligence and attitude [39].

\subsection{Social bullying}

Based on Figure 2 explained the findings of social bullying behavior in children aged 4-6 years show very varied data. There are eight social bullying terms or labels that appear in early childhood game mobile learning users. The eight terms of social bullying are (1) intimidating, (2) blaspheme, (3) scoffed, (4) lie, (5) scare, (6) spreading rumors, (7) humiliate others, and (8) isolate someone. The data in graph 2. can be explained that the dominance of social bullying in children using games mobile learning is on someone's isolation, scare, lie, and scoffed. Some of these social bullying behaviors are carried out by children aged 4-6 years with different intensities and frequencies.

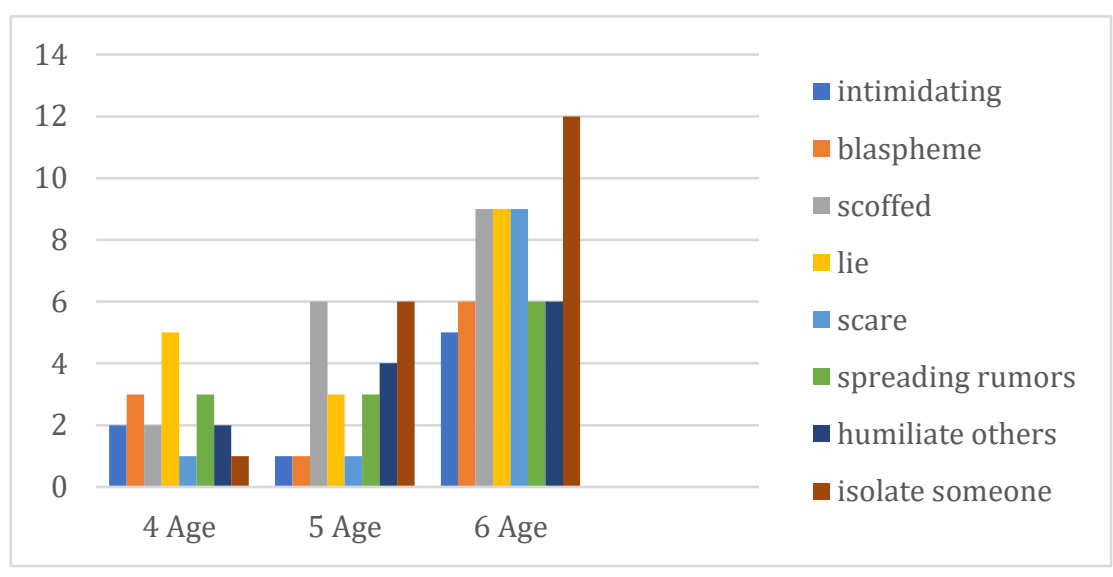

Fig. 2. The Graph Data of Types and Intensity of Social Bullying

The children aged four years tend to engage in social bullying by lying, spreading rumors, and blaspheme, and several other negative behaviors as shown in Fig 2. Lies and deviant behavior are inherently owned by all humans, including children. However, in the view of psychology and education, all deviant behavior can be changed even 
though in some cases it may take a long time. Behavioral deviations, including the habit of bullying, if left unchecked, will become an internalized character in every activity of human life [40]. If this happens, then every person's behavior will always be accompanied by negative behavior that tends to deviate from social values in general. Psychiatric aspects whose character is much more difficult to change than other deviant behaviors that have not yet taken root and have been internalized in a child's or someone's life [41]. The influence of the social and family environment is very decisive on the formation of children's behavior [42]. People who are close to children must be able to give positive messages to children, both in the form of physical behavior and oral information [43]. Persuasive and motivational behavior among parents, teachers, and other educators is indispensable in shaping and changing children's behavior [44].

Children aged five years tend to do social bullying in the form of scoffed, isolated someone, and humiliate others. Making fun of or insulting other children is a child's behavior that arises as a result of children's social interactions. This behavior is part of the child's effort to show his superiority in the eyes of the environment [45]. However, the behavior of mocking and criticizing or even insulting other children creates social estrangement between children and even between parents. In the study of child development psychology, the behavior of criticizing and taunting others will not last long because all the behavior that appears in them is part of the process of self-formation [42]. The behavior of taunting and criticizing others is easy to change at the same time when the child receives a reward or reward that is pleasantly appropriate for the child. For early childhood, rewards or gifts that are considered capable of changing their behavior are not always in the form of physical objects but can be in the form of verbal praise that is fun and uplifts their psychology [46]. Parents, teachers, and educators as well as anyone who has a close relationship with children must have an understanding and educational ability for students [47]. Parenting activities for parents are still very relevant to provide the same understanding of strategies for educating children that are in line with educational programs in schools.

Children aged 6 years tend to do social bullying to almost all types of bullying that children do. In order, the quality and frequency of social bullying carried out by children aged 6 years were isolated someone, scare, lie, scoffed, spreading issues, humiliating others, blaspheme, and intimidating. At the age of 6 years already can process words and thoughts that are close to perfect in the perspective of child development psychology. 6-year-olds also have the ability and courage to gather peers to build patterns of social interaction. However, it cannot be denied that the kinship and social processes of children will always clash with disappointments and self-protects associated with not fulfilling their expectations. Therefore, social bullying often occurs in early childhood. Physically and psychologically, children aged six years can exert pressure on other parties, especially their peers. Likewise, to his parents, Six-year-old child also has the will to force his will so that all his needs are met. In this context, social bullying occurs when a child feels that he is not being fulfilled what he wants. The principle of reciprocal or reciprocity is often used as a weapon for children to exert pressure on other parties, including their parents and peer environment. Once again, early childhood needs full attention from parents, so the existence and role of 
parents in making educational interactions are needed to help early childhood development.

\subsection{Physical bullying}

Physical bullying as depicted in Figure 3 that is done by children aged 4-6 years is (1) damaging things, (2) hurt herself, (3) hurting others, and (4) throw stuff away. Each of these bullying behaviors has a relatively average intensity and frequency for all groups of early childhood. Physical bullying is done to oneself and also to others, either by destroying things or hurting them physically.

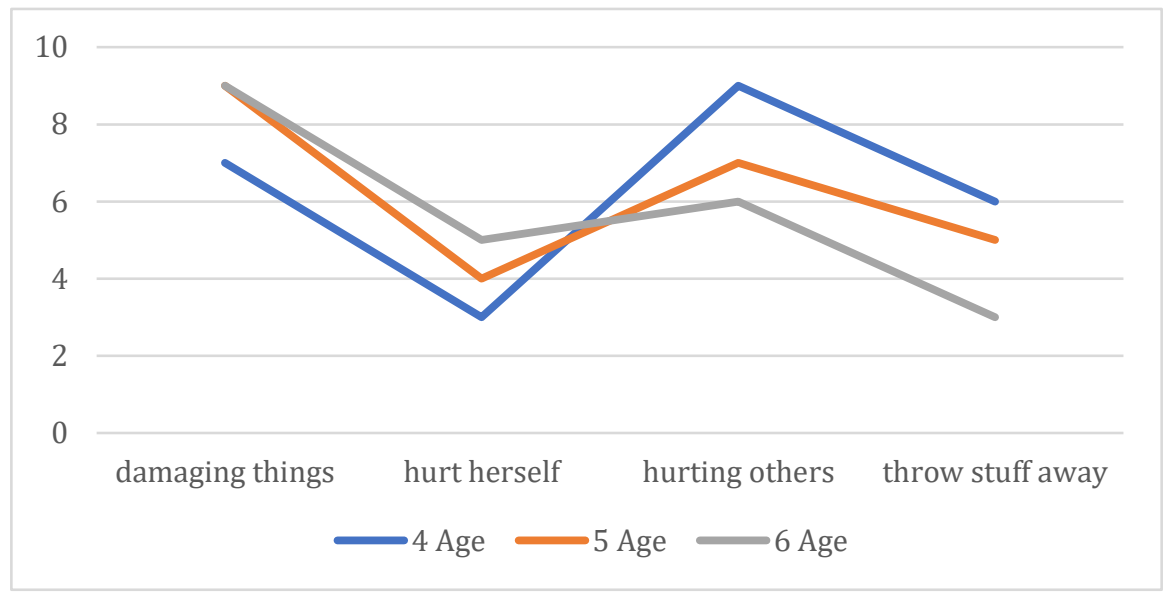

Fig. 3. The Graph Data of Types and Intensity of Physical Bullying

In sequence, the intensity of physical bullying that 4-year-olds do is hurting others, damaging things, throw stuff away, and hurt themselves. The quality or frequency of bullying is relatively similar. This data can be explained that all types of physical bullying have been carried out and befell children aged 4 years, even though the quality of the bullying did not cause serious damage or pain. However, this incident must be the concern of all parties related to early childhood education, especially efforts to prevent and stop these negative behaviors. Every child has certainly committed physical bullying but everyone must also be aware of this incident so that it does not lead to bullying that is even more dangerous, both to themselves and others.

Children aged five years tend to do physical bullying in the form of damaging things, hurting others, and throw stuff away, and then hurt themselves. The data show that the quality and frequency of physical bullying against various types of bullying by children aged five years are not too extreme. Physical bullying is an action that requires motor and physical movements that are guided by the will of the soul to do something, both to oneself and others. [48]. This incident is part of the child's development process that always appears in every child's movement in their environment. Parents and educators need the energy management of children's movement so that 
the direction of movement and physical development of children goes through the correct process according to development principles and tasks. Children's play and educational devices must be managed properly so that they are used properly according to their function as learning tools [49].

Almost all 6-year-olds do physical bullying with almost the same intensity between damaging things, hurting others, throw stuff away, and hurt themselves. This means that physical bullying behavior can easily be done by children aged six years by involving playing equipment as a trigger for the emergence of physical bullying. This can be understood because indeed physical movements at an early age including the age of 6 years have high intensity and quality, along with the presence of playing age in children. Early childhood will always move and play even without being triggered by play devices or other objects that children need. Children will look for and make use of objects in their environment to express themselves through various movements and imaginations of thoughts towards situations and events of other objects.

The following is a summary of the data in the graphical form regarding verbal bullying, social bullying, and physical bullying for each age group 4 years, five years, and six years. Figure 4 shows that bullying in the form of verbal bullying, social bullying, and physical bullying are all experienced and carried out by children aged 4-6 years with different intensities. Bullying that stands out for four-year-old is physical bullying followed by verbal bullying and social bullying. Children aged five years do bullying in the form of verbal bullying, namely physical bullying, and social bullying. Meanwhile, children aged six years dominate bullying in the form of social bullying followed by verbal bullying.

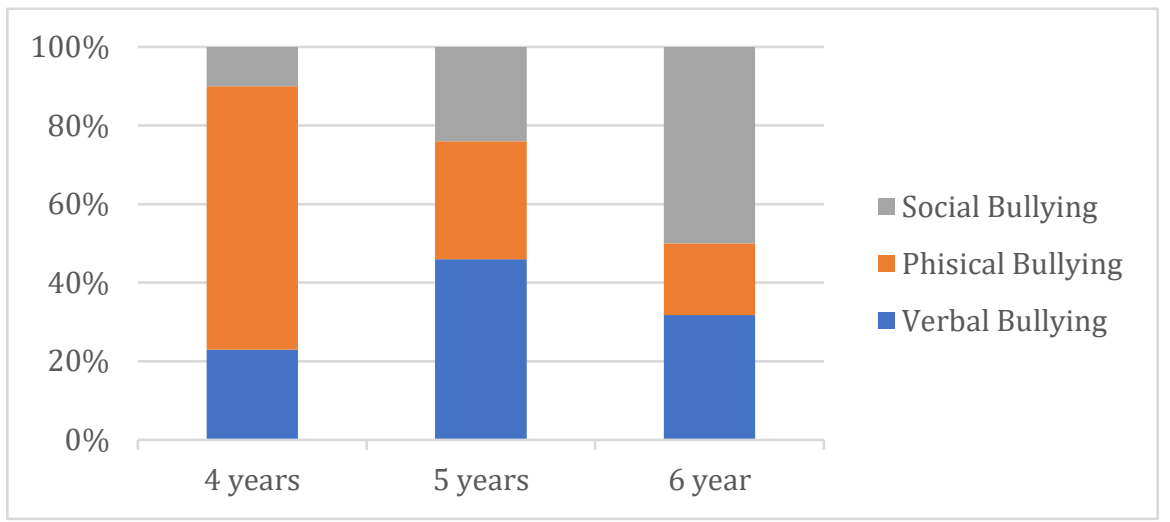

Fig. 4. The Summary Graph of Bullying Actions for Children aged 4-6 Years

The problem of bullying in early childhood is not only triggered by a game called game mobile learning. Many other potential triggers are bullying behavior in children. Based on a meta-analysis, game mobile learning data has a positive and negative impact on a learning process [50]. During this period, some children felt motivated and greatly helped by learning activities using game mobile learning [51]. In Finland, game mobile learning training can change the way adults think around children [52]. 
Game mobile learning is not as loud as they appear. Pedagogically, child educator teachers focus on peer learning, virtual environments, environmental awareness, storytelling, and physical involvement to train the simplicity of game mobile learning in the early childhood learning process [53]. Collaborative, creative, productive, and participatory learning activities when children learn to use game mobile learning are one of the solutions for how game mobile learning no longer limits the formation of children as sociable individuals [1], [44].

Game mobile learning is not the enemy, each party must always be careful in accompanying early childhood to negative behavior that is caused by users of game mobile learning (M. Wang et al., 2009). Although game mobile learning has eliminated almost all types of games native to local communities in the world that were once the pride of children in a country. in fact, traditional games can also be turned on into game mobile learning through innovative development of game mobile learning tools that are fun and friendly for children's development [1], [54]. Traditional games that are usually done outside the home are no longer activities that children can do freely, so game mobile learning is one of the children's learning options to gain knowledge (Surahman et al., 2020). Sorting the types of games, the ability to receive learning messages during the learning process using game mobile learning for children requires special learning management and assistance by the adults around them.

Game mobile learning describes the form of playing individually because they only interact with the use of an electronic game tool [30]. It can indirectly turn off the social sense inherent in children [55]. The frequency and intensity of play that takes hours without moving the limbs can also hinder their physical growth as well as psycho-social development. Playing game mobile learning, feeling bored, and feeling hopeless because of the defeat when playing games is very likely to happen to children. Game mobile learning can easily influence children's attitudes [30]. Experiencing depression, irritability, and taking anarchic action when you experience defeat while playing. On the other hand, winning when playing game mobile learning is also able to foster motivation, high enthusiasm, and excessive joy so that you don't want to stop playing and forget about time and responsibility. [32].

Insecure, depression, inability to control oneself, and boredom and addiction to playing game mobile learning need to be a special concern as a form of the disorder that occurs in children's personality development due to the use of game mobile learning [56]. Completing learning facilities using game mobile learning is an effort to full fill children's rights to learn by parents and teachers [41]. But without realizing it, this can also open up opportunities for failure in the formation of the child's personality and behavior towards the social surroundings. Slamming cell phones, cursing, and getting angry when you experience defeat at play are some forms of unsettling behavior that are left without the attention of adults around the child to direct and advise. Children who were asked about anger, cursing and did not want to make friends when playing learning games, apparently did not know and felt there was nothing. Caring and mentoring activities for adults around children is a form of management of mobile learning games to support their personality and early childhood education programs.

In a developmental psychology review, each child has uniqueness, abilities, and creativity as well as different developmental differences between children [57]. All 
children must be protected from bullying, both as perpetrators and victims. The growing period of children who are sensitive to outside influences must be protected from bad behavior that befell them, especially children aged 0-6 who are at the golden age stage [21]. Children in this phase have extraordinary growth in the aspects of cognition, language, physical, social-emotional, art, religious, and moral values in every developmental task [58]. In the golden age, children learned many new things and began to adapt to their surroundings such as the school environment, the environment around the house, and the social environment of their peers. Attention, protection, and proper stimulation are essential for the optimal growth and development of children. Inhibition of the child's growth and development at this stage can result in disruption of the child's social life skills in the future [59].

The development of the digital world is growing rapidly [60]. Changes in this era should not be a hindrance for various forms of innovation in learning in the world of education, especially education in early childhood [61]. Children are white papers and they still have to live and develop according to their times [62]. Based on the findings of this study, it shows that many bullying behaviors appear and develop without realizing it through learning activities using game mobile learning used by children. Children themselves do not understand the meaning of bullying behavior which is shown through attitudes, words, and behavior when playing game mobile learning. So, the expertise of the closest adults to the child is needed to manage learning activities using game mobile learning, provide intensive assistance for children when playing game mobile learning, provide good advice and admonitions when bullying behavior is presented by the child, and agree on clear rules. and firmly with children when playing game mobile learning.

\section{Conclusion}

The game mobile learning is part of achieving successful responses in education and innovation. This gives rise to many media services that can be chosen by the actors in educating children from an early age. However, the impact caused by the use of game mobile learning as a form of media for children to learn is very large on changes in attitudes and behavior that have the connotation of bullying, both verbally and nonverbally as well as other possible effects that have not been analyzed in this study.

In general, the results of this study can be concluded, that early childhood game mobile learning users are proven to generate new behaviors that can be interpreted as bullying. This bullying occurs aimed at other people as well as himself. Bullying carried out by early childhood users of games mobile learning is in the form of (1) verbal bullying, (2) social bullying, and (3) physical bullying. The intensity and quality of bullying by early childhood varies according to the frequency and intensity of children using games mobile learning. The longer the child uses the learning car game, the more frequent bullying will be. The farther away from parental supervision, the longer the child will use games mobile learning as a game tool. However, the impact of bullying on early childhood has not reached a stage that endangers themselves or 
others, but it must be done as soon as possible when the child is playing games mobile learning. This assistance is carried out to prevent an even worse impact on children's development.

Unconsciously, bullying behavior is formed and developed from an early age through game mobile learning used by children. Children do not understand the meaning of bullying behavior which is shown through attitudes, words, and behavior when playing game mobile learning. So, the closest person must immediately realize the need for intensive assistance and manage using game mobile learning for child to get goal of learning outcome.

\section{Acknowledgement}

We have a deep affection for all those who contributed to being involved in this qualitative research. Especially for informants, research teams, data collectors, and also the Managers at Universitas Negeri Malang and Universitas Negeri Yogyakarta who have supported the implementation of the research process.

\section{References}

[1] R. A. Dore et al., "Education in the app store: using a mobile game to support U.S. preschoolers' vocabulary learning," J. Child. Media, vol. 13, no. 4, pp. 452-471, Oct. 2019, doi: 10.1080/17482798.2019.1650788.

[2] L. F. M. G. Pedro, C. M. M. de O. Barbosa, and C. M. das N. Santos, "A critical review of mobile learning integration in formal educational contexts," Int. J. Educ. Technol. High. Educ., vol. 15, no. 1, 2018, https://doi.org/10.1186/s41239-018-0091-4

[3] M. Bahak Udin By Arifin, M. Sholeh, A. Hafiz Universitas Islam Kalimantan Muhammad Arsyad Al Banjari, I. Ririn Dwi Agustin, and M. Darmawan Kusuma Wardana, "Developing Interactive Mobile Mathematics Inquiry to Enhance Students' Mathematics Problemsolving Skill," Int. J. Interact. Mob. Technol., vol. 15, no. 01, pp. 24-38, Jan. 2021, https:// doi.org/10.3991/ijim.v15i01.20067

[4] A. Rasyid and A. Gaffar, "Pengembangan Aplikasi Mobile Learning Model Games 'Antibody vs Antigen' Menggunakan RPG Maker MV pada Pembelajaran Biologi Konsep Sistem Imun," BIODIK, vol. 5, pp. 225-238, Dec. 2019, https://doi.org /10.22437/bio.v5i3.7870

[5] Iswinarti and D. R. Suminar, "Improving children's problem-solving skills through javanese traditional games," Cakrawala Pendidik., vol. 38, no. 3, pp. 578-589, Jun. 2019, https://doi.org/10.21831/cp.v38i3.25331

[6] E. Nur Aisyah, R. Tri Wulandari, E. Mastutik, S. Wahyuni, and N. Harjati, "Strategy for Investing the Value of Nationalism Characters through Fairytale and Dance for Early Childhood," 2018, https://doi.org/10.2991/coema-18.2018.37

[7] C. P. Monks and P. K. Smith, "Definitions of bullying: Age differences in understanding of the term, and the role of experience," British Journal of Developmental Psychology, vol. 24, no. 4. pp. 801-821, Nov. 2006, https://doi.org/10.1348/026151005x82352

[8] S. M. Swearer and S. Hymel, "Understanding the psychology of bullying: Moving toward a social-ecological diathesis-stress model," Am. Psychol., vol. 70, no. 4, pp. 344-353, May 2015, https://doi.org/10.1037/a0038929 
[9] R. Sittichai and P. K. Smith, "Bullying in South-East Asian Countries: A review," Aggression and Violent Behavior, vol. 23. Elsevier Ltd, pp. 22-35, Jul. 01, 2015, https://doi. org/10.1016/j.avb.2015.06.002

[10] L. Grunin, G. Yu, and S. S. Cohen, "The Relationship Between Youth Cyberbullying Behaviors and Their Perceptions of Parental Emotional Support," Int. J. Bullying Prev., 2020, https://doi.org/10.1007/s42380-020-00080-5

[11] C. A. Rose, D. M. Richman, K. Fettig, A. Hayner, C. Slavin, and J. L. Preast, "Peer reactions to early childhood aggression in a preschool setting: Defenders, encouragers, or neutral bystander," Dev. Neurorehabil., vol. 19, no. 4, pp. 246-254, Jul. 2016, https://doi.org/ $\underline{10.3109 / 17518423.2014 .979955}$

[12] O. N. Saracho, "Bullying Prevention Strategies in Early Childhood Education," Early Child. Educ. J., vol. 45, no. 4, pp. 453-460, Feb. 2017, https://doi.org/10.1007/s10643016-0793-y

[13] K. L. Modecki, J. Minchin, A. G. Harbaugh, N. G. Guerra, and K. C. Runions, "Bullying prevalence across contexts: A meta-analysis measuring cyber and traditional bullying," Journal of Adolescent Health, vol. 55, no. 5. Elsevier USA, pp. 602-611, Nov. 01, 2014, https://doi.org/10.1016/j.jadohealth.2014.06.007

[14] Indonesian government, Undang-Undang Republik Indonesia Nomor 23 Tahun 2002 Tentang Perlindungan Anak Dengan Rahmat Tuhan Yang Maha ESA Presiden Republik Indonesia.2002.https://doi.org/10.33363/bb.v8i1.344

[15] P. K. Smith and S. Robinson, "How Does Individualism-Collectivism Relate to Bullying Victimisation?" Int. J. Biling., vol. 1, pp. 3-13, 2019, https://doi.org/10.1007/s42380-0180005-y

[16] A. D. Arumsari, Suminten, R. Zuro Ida hanum, and I. Hidayati, "Bullying Pada Anak USIA DINI," MOTORIC, vol. 1, no. 1, p. 8, Apr. 2018, doi: 10.31090/paudmotoric.v1i1.550

[17] B. S. Hewett and K. M. La Paro, "Organizational Climate: Collegiality and Supervisor Support in Early Childhood Education Programs," Early Child. Educ. J., vol. 48, pp. 415427, 2020, https://doi.org/10.1007/s10643-019-01003-w

[18] D. Olweus, S. P. Limber, and K. Breivik, "Addressing Specific Forms of Bullying: A Large-Scale Evaluation of the Olweus Bullying Prevention Program," Int. J. Bullying Prev., vol. 1, pp. 70-84, 2019, https://doi.org/10.1007/s42380-019-00009-7

[19] P. Si and I. Astu, Pengembangan Resiliensi Sekolah untuk Mengurangi Bullying di Sekolah Berbasis Modal Sosial. Universitas Negeri Yogyakarta, 2020. https://doi.org/10.21063/ spi3.1017.150-157

[20] M. Ojala, Danielle, E. Ladru, and · Katarina Gustafson, "Parental Reasoning on Choosing the Mobile Preschool: Enabling Sustainable Development or Adjusting to a Neoliberal Society?" Early Child. Educ. J., 2020, https://doi.org/10.1007/s10643-020-01083-Z

[21] E. Nur Aisyah, T. Iriyanto, H. Hardika, A. Samawi, and R. Twin Maningtyas, "Pengembangan Inovasi Pendidikan Prasekolah Di Lingkungan Binaan Um Berbasis Mastery Progresif | Aisyah | Jurnal Graha Pengabdian,” Jurnal Graha Pengabdian, 2019. http://journal2.um.ac.id/index.php/jgp/article/view/9960 (accessed Aug. 15, 2020).

[22] Z. Zaharah and G. Kirilova, "Impact of Corona Virus Outbreak Towards Teaching and Learning Activities in Indonesia," SALAM J. Sos. dan Budaya Syar-i, vol. 7, Mar. 2020, https://doi.org/10.15408/sjsbs.v7i3.15104

[23] R. Zainul et al., "Development of e-Learning Courses for Subjects about 'Learn and Learning' with Moodle-based for Prospective Teacher in Indonesia," J. Phys. Conf. Ser., vol. 1594, no. 1, p. 012023, Jul. 2020, https://doi.org/10.1088/1742-6596/1594/1/012023

[24] H. Hardika, E. Nur Aisyah, T. Kurniawan, and U. Negeri Malang, "Literacy about Covid19: Trending Words, News Sources, Compre-hension, and Community Curiosity in Perspectives Nonformal Edu-cation History Article," J. Nonform. Educ., vol. 6, no. 2, pp. 161-167, Aug. 2020, doi: 10.15294/jne.v6i2.24898. 
[25] R. Djalante et al., "Review and analysis of current responses to COVID-19 in Indonesia: Period of January to March 2020," Prog. Disaster Sci., vol. 6, p. 100091, Apr. 2020, https://doi.org/10.1016/j.pdisas.2020.100091

[26] H. Hardika, E. Nur Aisyah, K. Miroso Raharjo, and D. Umnia Soraya, "Transformation the Meaning of Learning for Millennial Generation on Digital Era," Int. J. Interact. Mob. Technol., vol. 14, no. 12, pp. 69-81, Jul. 2020, https://doi.org/10.3991/ijim.v14i12.15579

[27] P. Ananto and S. Kusuma Ningsih, "Incorporation of Smartphones and Social Media to Promote Mobile Learning in an Indonesian Vocational Higher Education Setting," Int. J. Interact. Mob. Technol., vol. 14, no. 19, pp. 66-81, Nov. 2020, https://doi.org/10.3991/ijim.v14i19.13863

[28] N. K. Lai, T. F. Ang, L. Y. Por, and C. S. Liew, "The impact of play on child development - a literature review," Eur. Early Child. Educ. Res. J., vol. 26, no. 5, pp. 625-643, Sep. 2018, doi: 10.1080/1350293X.2018.1522479.

[29] R. M. Tawafak et al., "Impact of Technologies During COVID-19 Pandemic for Improving Behavior Intention to Use... Impact of Technologies During COVID-19 Pandemic for Improving Behavior Intention to Use E-learning Ragad M Tawafak ( $\square$ ), Int. J. Interact. Mob. Technol., vol. 15, no. 01, pp. 184-198, Jan. 2021, https://doi.org/10.3991/ijim.v15i01.17847

[30] M. Wang, R. Shen, D. Novak, and X. Pan, "The impact of mobile learning on students' learning behaviours and performance: Report from a large blended classroom," $B r . J$. Educ. Technol., vol. 40, no. 4, pp. 673-695, 2009, https://doi.org/10.1111/j.14678535.2008.00846.x

[31] M. J. Wang and R. M. Shen, "Increasing interactivity in large blended classrooms through a cutting-edge mobile learning system," in 2008 ITI 6th International Conference on Information and Communications Technology, ICICT 2008, 2008, pp. 59-63, https://doi.org/ $10.1109 /$ itict.2008.4806642

[32] J. Robertson, "Making games in the classroom: Benefits and gender concerns," Comput. Educ., vol. 59, no. 2, pp. 385-398, Sep. 2012, https://doi.org/10.1016/j.compedu.2011. $\underline{12.020}$

[33] J. Mitchell, "A More Comprehensive Approach to Antibullying Programs: Interventions in the School and Home," Capella University, 2019.

[34] H. Hardika, E. Nur Aisyah, and I. Gunawan, Buku Transformasi Belajar Generasi Milenial, 1st ed. Malang: UM Pers, 2019.

[35] E. N. Aisyah, T. Iriyanto, H. Hardika, Rosyidamayani, and T. Maningtyas, "The Cyber Ethics of Academic Communication Based on Early Childhood Education Student Perception in Universitas Negeri Malang," in Proceedings of the International Conference on Learning Innovation 2019 (ICLI 2019), Jul.2020,pp.1-5, https://doi.org/ 10.2991/assehr.k.200711.001

[36] R. Helyer, "Learning through reflection: the critical role of reflection in work-based learning (WBL)," J. Work. Manag., vol. 7, no. 1, pp. 15-27, Jan. 2015, https://doi.org/10.1108/jwam-10-2015-003

[37] E. Nur Aisyah and Hardika, "Politeness in the Contemporary Perspective," 2019, https://doi.org/10.2991/icet-18.2018.7

[38] V. Terziev, "Factors Affecting the Process of Social Adaptation," Social Science Research Network, Rochester, NY, Jan. 2017. [Online]. Available: https://papers.ssrn.com labstract $=3143186$

[39] E. Savina, "Self-regulation in Preschool and Early Elementary Classrooms: Why It Is Important and How to Promote It," Early Child. Educ. J., 2020, https://doi.org/10.1007/ s10643-020-01094-w

[40] E. Nur Aisyah, "Character Building in Early Childhood Through Traditional Games," Oct. 2017, https://doi.org/10.2991/icet-17.2017.51 
[41] B. M. Newman and P. R. Newman, Development Through Life: A Psychosocial Approach. Cengage Learning, 2017.

[42] L. Arseneault, L. Bowes, and S. Shakoor, "Bullying victimization in youths and mental health problems: Much ado about nothing?" Psychol. Med., vol. 40, no. 5, pp. 717-729, May 2010, https://doi.org/10.1017/s0033291709991383

[43] S. V. Jensen, "Difference and closeness: Young children's peer interactions and peer relations in school," Childhood, vol. 25, no. 4, pp. 501-515, Nov. 2018, https://doi.org/ $10.1177 / 0907568218803437$

[44] J. A. Durlak, R. P. Weissberg, A. B. Dymnicki, R. D. Taylor, and K. B. Schellinger, "The Impact of Enhancing Students' Social and Emotional Learning: A Meta-Analysis of School-Based Universal Interventions," Child Dev., vol. 82, no. 1, pp. 405-432, Jan. 2011, https://doi.org/10.1111/j.1467-8624.2010.01564.x

[45] D. Blazar and M. A. Kraft, "Teacher and Teaching Effects on Students' Attitudes and Behaviors," Educ. Eval. Policy Anal., vol. 39, no. 1, pp. 146-170, Dec. 2017, doi: 10.3102/ 0162373716670260.

[46] M. J. Haslip, A. Allen-Handy, and · Leona Donaldson, "How do Children and Teachers Demonstrate Love, Kindness and Forgiveness? Findings from an Early Childhood Strength-Spotting Intervention," Early Child. Educ. J., vol. 47, pp. 531-547, 2019, https://doi.org/10.1007/s10643-019-00951-7

[47] M. Elfert, "Lifelong learning in Sustainable Development Goal 4: What does it mean for UNESCO's rights-based approach to adult learning and education?" Int. Rev. Educ., vol. 65, no. 4, pp. 537-556, Dec. 2019, https://doi.org/10.1007/s11159-019-09788-z

[48] P. Pramono and E. Nur Aisyah, "Development of Early Childhood Physical Activity Game Model," 2018, https://doi.org/10.2991/ecpe-18.2018.35

[49] A. Thornton and T. Clutton-Brock, "Social learning and the development of individual and group behaviour in mammal societies," Philosophical Transactions of the Royal Society B: Biological Sciences, vol. 366, no. 1567. pp. 978-987, 2011, https://doi.org/10.1098/rstb. $\underline{2010.0312}$

[50] S. Davie, "Mobile learning in early childhood education: A school-university Mobile learning in early childhood education: A school-university partnership model partnership model,” 2017. Accessed: Jan. 26, 2021. [Online]. Available: https://researchonline.nd.edu.au/theses

[51] K. Demir and E. Aknipar, "The effect of mobile learning applicationson students' academic achievement andattitudes toward mobile learning," Malaysian Online Journal of Educational Technology, 2018. https://files.eric.ed.gov/fulltext/EJ1174817.pdf (accessed Jan. 26, 2021). https://doi.org/10.17220/mojet.2018.02.004

[52] P. Marjanen, O. Ojajärvi, S. Kumar, and A. Kumar, "Game for Children to Support Social Skills," in INTED2018 Proceedings, Mar. 2018, vol. 1, pp. 3354-3362, https://doi.org/10.21125/inted.2018.0647

[53] S. Sintonen, O. Ohls, K. Kumpulainen, and L. Lipponen, Mobile Learning and the Playing Child Can I Draw? 2015.

[54] K. Zhampeissova and I. Kosareva, "Collaborative Mobile Learning with Smartphones in Higher Education," Int. J. Interact. Mob. Technol., vol. 14, no. 21, pp. 4-18, Dec. 2020, https://doi.org/10.3991/ijim.v14i21.18461

[55] M. E. Taylor and W. Boyer, "Play-Based Learning: Evidence-Based Research to Improve Children's Learning Experiences in the Kindergarten Classroom," Early Child. Educ. J., vol. 48, pp. 127-133, 2020, https://doi.org/10.1007/s10643-019-00989-7

[56] G. J. Hwang, C. M. Hung, and N. S. Chen, "Improving learning achievements, motivations and problem-solving skills through a peer assessment-based game development approach," Educ. Technol. Res. Dev., vol. 62, no. 2, pp. 129-145, 2014, https://doi.org/10. 1007/s11423-013-9320-7 
[57] E. Menesini and C. Salmivalli, "Bullying in schools: the state of knowledge and effective interventions," Psychol. Heal. Med., vol. 22, pp. 240-253, Mar. 2017, https://doi.org/ $10.1080 / 13548506.2017 .1279740$

[58] A. Lake, "Early childhood development - Global action is overdue," Lancet, vol. 378, no. 9799, pp. 1277-1278, 2011, https://doi.org/10.1016/s0140-6736(11)61450-5

[59] G. J. Kim and M. Umayahara, "Early Childhood Care and Education: Building the Foundation for Lifelong Learning and the Future of the Nations of Asia and the Pacific," International Journal of Child Care and Education Policy, vol. 4, no. 2. Springer, pp. 1-13, Nov. 01, 2010, https://doi.org/10.1007/2288-6729-4-2-1

[60] S. Higgins, Z. Xiao, and M. Katsipataki, "The Impact of Digital Technology on Learning: A Summary for the Education Endowment Foundation Full Report," 2012.

[61] L. Plowman, C. Stephen, and J. McPake, Growing up with technology: Young children learning in a digital world. Routledge Taylor \& Francis Group, 2009.

[62] K. Rentzou, "Greek early childhood educators' conceptualization of education, care and educare concepts," Early Years, vol. 39, no. 2, pp. 148-162, Apr. 2019, https://doi.org/ $\underline{10.1080 / 09575146.2017 .1361386}$

\section{$7 \quad$ Authors}

Eny Nur Aisyah is a lecturer in the Early Childhood Education Department, Faculty of Education at Universitas Negeri Malang Indonesia and and now he is also a student in the Doctoral Program of Educational Science in the Early Childhood of Education Concentration Universitas Negeri Yogyakarta. She is a consultant in early childhood education at Dunia Anak, and a member of the National Association in Early Childhood Education. She is a reviewer of the Golden Age Journal at Islamic Bandung University in Indonesia and the researcher was concerned in learning innovations for early childhood education development and others.

Harun, is a professor in the Early Childhood Education Department, Faculty of Education at Universitas Negeri Yogyakarta Indonesia. He is an outstanding lecturer at Universitas Negeri Yogyakarta, and also active in the field of research on assessment, evaluation in early childhood education development character. He is an active member of the Indonesian Early Childhood Educators Association. He is the winner of the best national dissertation writer, and also a writer dan a reviewer in several national and international journals, harun@uny.ac.id

Arif Rohman, is a doctor and senior lecturer in the Science Education Department, Faculty of Educatio and the head of the department of the doctoral program science of education at Universitas Negeri Yogyakarta. He is also a member of the Indonesian Social Science Education Association. A writer dan a reviewer in several national and international journals and he is concerned in research in the field of quality development in educational policy, and character education in socio-culture. He is also a speaker in scientific forums at national conference. arif rohman@uny.ac.id

Hardika is a doctor and senior lecturer in the Non-formal Education Department. $\mathrm{He}$ is he is the accelerated team of scientific publications faculty of education at Universitas Negeri Malang Indonesia. He is also a member of the IEEE Publisher. He is the editor of several journals at Universitas Negeri Malang there is the Journal of Education Faculty of Education and International Research-Based Educational Journal 
Faculty of Education. He is a reviewer for the Annual International Conference of Education and Training (ICET) and International Conference on Early Childhood and Primary Education Faculty of Education Universitas Negeri Malang. He is also an active member of the Indonesian Non-Normal and Informal Educators Association, and member of the Indonesian Social Education Association. hardika.fip@um.ac.id

Article submitted 2021-01-28. Resubmitted 2021-03-05. Final acceptance 2021-03-06. Final version published as submitted by the authors. 